\title{
Navigating Without Maps: Constitutional Silence and the Management of the Brexit Crisis
}

\section{Aileen McHarg}

\section{Introduction}

No constitution can ever be wholly reduced to text. ${ }^{1}$ All contain gaps and abeyances ${ }^{2}$ which require to be filled, bridged, or perhaps simply avoided in the day-to-day operation of the constitution. Silence is, however, a particularly notable feature of the United Kingdom's (UK) uncodified constitution. There is unusually heavy reliance on constitutional conventions, or other constitutional "soft law", ${ }^{3}$ to regulate basic features of the governmental system; such rules by their nature - frequently backwardlooking, and lacking authoritative means of interpretation or enforcement - being often limited in scope and uncertain in effect. In addition, the doctrine of Parliamentary Sovereignty, by rendering all other constitutional rules and principles legally contingent, has had the effect of inhibiting the development of a normatively "thick" understanding of the terms and conditions of legitimate constitutional authority. ${ }^{4}$ Although both features of the constitution have come under challenge in recent decades, it remains in important respects a "political" rather than a "legal" one. ${ }^{5}$

Silence carries substantial advantages in the management of constitutional relations. ${ }^{6}$ It allows for flexibility in responding to constitutional problems. It also leaves space for a plurality of voices and claims in situations where appropriate constitutional principles and/or procedures are contested, without having to make potentially divisive choices between them. ${ }^{7}$ By reducing both "decision costs" and "error costs" in constitutional rule-making, ${ }^{8}$ these features are generally regarded as central explanations for the longevity of the UK's constitutional arrangements. Nevertheless, constitutional silence also has potential disadvantages: uncertainty over the basic rules of the political game; ${ }^{9}$ lack of transparency; the risks of prioritising expediency over principle, of abuse of power, and of structurally favouring or disfavouring certain interests or positions within constitutional debates.

Both the advantages and disadvantages of constitutional silence can be seen most clearly in times of political crisis. In The Silence of Constitutions, Foley makes a powerful case for the value of constitutional silence as a reservoir of strategic ambiguity which helps the constitutional order to survive crises by diffusing rather than confronting and resolving conflicts over fundamental rules and principles. The flexibility that constitutional silence affords can permit creative solutions to political crises which avoid the need to determine in a definitive fashion the scope and limits of the constitutional authority of different institutions and actors. However, where the political conditions

\footnotetext{
${ }^{1}$ L.H. TRIBE, THE INVISIBLE CONSTITUTION (2008).

${ }^{2}$ M. FOLEY, THE SILENCE OF CONSTITUTIONS: GAPS, ABEYANCES AND POLITICAL TEMPERAMENT IN THE MAINTENANCE OF GOVERNMENT (1989).

${ }^{3}$ See A. MCHARG, Reforming the United Kingdom Constitution: Law, Convention, Soft Law, 71 MLR 853 (2008); C. SCOTT, Regulating Constitutions, in C. PARKER ET AL (EDS), REGULATING LAW (2004).

${ }^{4}$ Cf. N. WALKER, Our Constitutional Unsettlement, PL 529, 533 (2014).

${ }^{5}$ See J.A.G. GRIFFITH, The Political Constitution, 42 MLR 1 (1979).

${ }^{6}$ See FOLEY, supra $\mathrm{n} 2$.

${ }^{7}$ N. BARBER, Against a Written Constitution, PL 11, 15- 18 (2008).

${ }^{8}$ R. DIXON and T. GINSBURG, Deciding Not to Decide: Deferral in Constitutional Design, 9 ICON 636 (2011).

${ }^{9}$ Uncertainty and flexibility are not merely two sides of the same coin. There may be flexibility to change rules, yet certainty over their content as they currently exist; conversely, there may be uncertainty about the meaning of rules, without significant flexibility to change them.
} 
(or "social temperament") for the maintenance of silence breaks down - i.e., where there ceases to be mutual benefit in maintaining constitutional silence - constitutional abeyances may themselves "become the subject of heightened interest and subsequent conflict" ${ }^{10}$, in which political crisis spills over into constitutional crisis. In these circumstances, Foley argues that constitutional abeyances "are not merely accompanied by an intense constitutional crisis, they are themselves the essence of that crisis." ${ }^{11}$ In other words, whereas the existence of clear constitutional guidelines might help with the navigation of unfamiliar political terrain, their elusiveness may itself become a constitutional problem, potentially triggering a wider crisis of constitutional legitimacy. At the same time, Foley suggests that "constitutional crises are of great value as they reveal in dramatic form what had been concealed in agreeable ambiguity." 12

In this article, I explore the role of constitutional silence in navigating the crisis engendered by the vote, by a narrow majority (51.9 per cent), in the referendum of 23 June 2016 for the UK to leave the European Union (EU) ("Brexit"). This may fairly be described as having produced a crisis in at least three respects.

First, there was radical uncertainty over the meaning of Brexit. For a Member State to leave the EU after more than 40 years of legal and political integration was unprecedented, and the procedure for doing so (under Article 50 of the Treaty on European Union) was relatively new ${ }^{13}$ and untested, and in some respects unclear. The implications for the extensive policy areas currently governed by EU law, for the UK's future relationship with the EU, and for its wider place in the world, were issues with economic, political, legal, social, cultural, environmental, and national security implications. Yet, little or no advance planning appeared to have been done either by the UK Government, which promoted the referendum, or those advocating a Leave vote.

Secondly, geographic variations in the referendum result - a majority of voters in England (53.4 per cent) and Wales (52.5 per cent) voted to Leave the EU, while majorities in Scotland (62 per cent) and Northern Ireland (55.8 per cent) voted to Remain - exacerbated pre-existing tensions in territorial relations within the UK. The removal of one tier of the UK's system of multi-level governance necessarily raised questions about the future distribution of competences between the UK and devolved governments, potentially signalling a radical recasting of the territorial constitution. More seriously, the prospect of a hard border between Northern Ireland and the Irish Republic threatened one of the pillars upon which Northern Ireland's peace process had been built. ${ }^{14}$ And in Scotland, withdrawal from the EU against the wishes of Scottish voters had been explicitly stated by the governing Scottish National Party (SNP) as amounting to a "material change in circumstances" since the 2014 independence referendum sufficient to justify a second independence vote. ${ }^{15}$ Immediately after the Brexit referendum, the Scottish First Minister, Nicola Sturgeon, made clear that the option of a second independence referendum was firmly "on the table". ${ }^{16}$

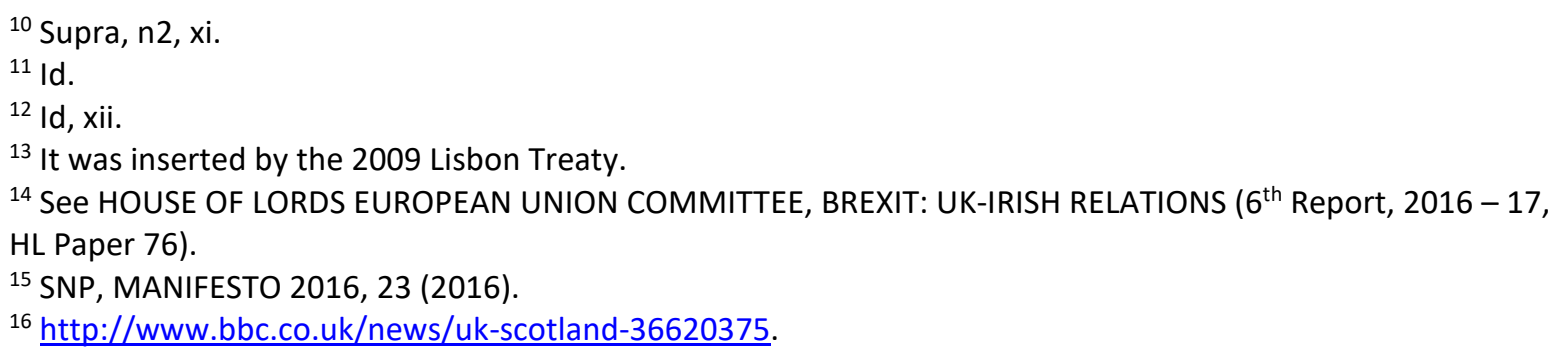


Thirdly, the referendum result provoked a crisis of political authority. In the aftermath of the vote, a leadership vacuum emerged, with the resignation of the Conservative Prime Minister, David Cameron, and of the UK Independence Party (UKIP) leader, Nigel Farage, as well as the launch of a leadership challenge against Jeremy Corbyn, leader of the main opposition (Labour) party. More fundamentally, the referendum exposed a rift between the UK's political elites (the majority of whom strongly supported remaining within the EU) and the wider electorate, particularly amongst the politically disengaged. ${ }^{17}$ The reaction of many Remain voters indicated a significant absence of losers' consent, which resulted in several - ultimately successful - legal challenges arguing that the government could not trigger the process of withdrawing from the EU on the strength of the referendum alone.

At the time of writing, 17 months on from the referendum, the immediate political crisis has receded. Although in January 2017, an unprecedented 11-judge bench of the Supreme Court ruled (by an 8-3 majority) in $R$ (Miller) $v$ Secretary of State for Exiting the European Union ${ }^{18}$ that an Act of Parliament was required to authorise Brexit, legislation was subsequently enacted to do so (the European Union (Notification of Withdrawal) Act 2017). The Prime Minister duly gave formal notification of the UK's intention to withdraw from the EU under Article 50 at the end of March 2017,19 and withdrawal negotiations began in June 2017. A further European Union (Withdrawal) Bill is also currently before the UK Parliament to regulate the domestic legal implications of Brexit, and the prospect of a second Scottish independence referendum has receded, following a snap UK general election held in May 2017 at which the SNP's share of votes and seats fell. However, much remains unclear. The unexpected loss of her House of Commons majority in the May election has weakened the Prime Minister's political authority; the Cabinet remains divided on the desired outcome of the withdrawal negotiations; the implications of Brexit for the powers of the devolved legislatures are highly contested; it is unclear how the UK Government's stated desire to maintain an open border between Northern Ireland and the Irish Republic will be realised; ${ }^{20}$ and the possibility of reversing the Article 50 notification, and thereby stopping Brexit, remains widely discussed. ${ }^{21}$ Clearly, the Brexit crisis is not over yet.

This article does two things. First, I argue that events since the EU referendum have exposed, and been shaped by, three key areas of constitutional silence. These concern: the constitutional authority of the referendum itself; the extent of the UK government's prerogative powers in foreign affairs; and the right of the Scottish people to secede from the UK. In exploring the nature and roots of each area of uncertainty, I seek to show how they stem from deep structural features of the UK's constitution. Second, I consider how silence has contributed, positively or negatively, to the management of the post-referendum crisis, asking whether what is undoubtedly a crisis for the UK constitution has also

\footnotetext{
${ }^{17}$ See J. CURTICE, How Leave Won Amongst the Politically Disengaged, WHAT UK THINKS EU BLOG, 20 December 2016 (http://whatukthinks.org/eu/how-leave-won-amongst-the-politically-disengaged/) 18 [2017] UKSC 5.

${ }^{19}$ Letter from Theresa May to Donald Tusk, 29 March 2017 (https://www.gov.uk/government/uploads/system/uploads/attachment data/file/604079/Prime Ministers I etter to European Council President Donald Tusk.pdf).

${ }^{20}$ HM GOVERNMENT, THE UNITED KINGDOM'S EXIT FROM AND NEW PARTNERSHIP WITH THE EUROPEAN UNION (Cm 9417, 2017) §4.4.

${ }^{21}$ Albeit it is an option which would face formidable obstacles, both legal and political - see C. HANRETTY, Exiting Brexit: tl;dr: Ain't Gonna Happen, MEDIUM.COM (10 September 2017) (https://medium.com/@chrishanretty/exiting-brexit-3902558a3fdb).
} 
become a crisis of the UK constitution. ${ }^{22}$ To begin with, however, the background to the EU referendum, the referendum process, and the Article 50 withdrawal procedure will be briefly outlined.

\section{The European Union Referendum 2016}

The EU referendum originated in a promise made by David Cameron in $2013,{ }^{23}$ then included in the 2015 Conservative election manifesto. ${ }^{24}$ There was no constitutional imperative to hold the referendum. Rather, the motivation was political: an attempt to resolve long-standing divisions in the Conservative party over the merits of EU membership, and to respond to the increasing electoral popularity of the ultra-Eurosceptic UKIP. The UK Government's own position - following a modest renegotiation of the terms of the UK's membership ${ }^{25}$ - was to advocate a Remain vote, although collective responsibility was suspended to allow individual ministers to campaign to Leave.

The referendum was authorised by the European Referendum Act 2015, and conducted in accordance with the Political Parties, Elections and Referendums Act (PPERA) 2000, Part 7 (as modified by the 2015 Act). The legislation did not provide for any special majority or turnout threshold. The only major controversy in this regard was an unsuccessful attempt by SNP MPs to amend the Bill to provide for a double majority requirement - i.e., that a UK-wide majority plus majorities in each of England, Scotland, Wales, and Northern Ireland would be required in order for Leave to win. Nor did the 2015 Act specify the consequences of the vote. While it was therefore acknowledged that the referendum was in legal terms merely advisory, it was nevertheless presented as giving "the British people the final say on our EU membership". ${ }^{26}$ According to the Government, in the event of a Leave vote, it "would have a democratic duty to give effect to the electorate's decision" by triggering Article 50, "and the British people would rightly expect that to start straight away."27

Article 50 itself merely provides that "[a]ny Member State may decide to withdraw from the Union in accordance with its own constitutional requirements" (emphasis added) and that "[a] Member State which decides to withdraw shall notify the European Council of its intention." Thereafter the Article provides for negotiation between the withdrawing and the remaining Member States over the terms of withdrawal, and for the Treaties to cease to apply to the withdrawing state on the entry into force of the withdrawal agreement, or at the end of two years (unless the negotiating period is extended by unanimous agreement).

\section{Constitutional Silence: Causes and Effects}

\section{a. The Constitutional Authority of the Referendum}

Despite its pre-referendum promise, the Government did not trigger Article 50 immediately following the Leave vote. Instead, when announcing his resignation on the morning of 24 June, Cameron

\footnotetext{
${ }^{22}$ Cf M. GORDON, Brexit: a Challenge for the UK Constitution, of the UK Constitution?, 12 ECL REVIEW 409 (2016).

${ }^{23}$ D. CAMERON, EU Speech at Bloomberg (23 January 2013) (http://www.gov.uk/government/speeches/euspeech-at-bloomberg).

${ }^{24}$ For the background, see M. D'ARCY, Brexit: How Rebel MPs Outfoxed Cameron to Get an EU Referendum, BBC NEWS WEBSITE (29 December 2016) (http://www.bbc.co.uk/news/uk-politics-parliaments-38402140). ${ }^{25}$ http://www.consilium.europa.eu/en/press/press-releases/2016/02/19-euco-conclusions/

${ }^{26}$ P. HAMMOND MP, HC Deb. Vol. 596, col. 1047 (9 June 2015).

${ }^{27}$ HM GOVERNMENT, THE PROCESS FOR WITHDRAWING FROM THE EUROPEAN UNION (Cm 9216, 2016$) \S 2.1$.
} 
declared that, although the Leave result must be respected, it should be for the new Prime Minister to take the decision when to implement it.

It is clear that Cameron's decision was not unlawful. Given that the 2015 Act specified no legal consequences of a Leave vote, a further decision had to be made to trigger the legal step of notifying withdrawal. But the question it opened up was whether the referendum result was sufficient to justify a withdrawal notification; in other words, whether the referendum could be said to satisfy the UK's "constitutional requirements" for a decision to withdraw from the EU, or if some further process was required. In so doing, it created space for debate about what constitutional authority - if any - should be accorded to the referendum.

What followed was an extraordinary outpouring of criticism - from politicians, journalists, lawyers, academics, and ordinary citizens - of the legitimacy of the referendum process, the quality of the referendum debate, and indeed of the compatibility of referendums with the UK's tradition of representative democracy; ${ }^{28}$ criticisms which had barely surfaced in debates over the European Union Referendum Bill, ${ }^{29}$ or during the referendum campaign. Some openly argued that the referendum result should be ignored; others that some further democratic process - an extraordinary general election, a second referendum, a vote in Parliament - was required to confirm the Leave decision. Opposition eventually crystallised around a series of judicial review actions, raised in the English and Northern Irish courts, and culminating in the Supreme Court decision in Miller, arguing that an Act of Parliament was required to authorise the government to trigger Article 50.

The challenge in Miller was carefully framed to avoid a direct attack on the authority of the referendum. Instead, as will be discussed further below, it was presented as a question about the scope of the UK Government's prerogative powers. Both the majority and minority in the Supreme Court took pains to emphasise that the case had nothing to do with the merits of Brexit, ${ }^{30}$ and that although the referendum result was not legally binding it did nevertheless have great political significance. Indeed, the minority judgments in particular stressed the fundamentally important interplay of legal and political constraints on government within the British constitutional tradition. ${ }^{31}$ Nevertheless, the majority decision in Miller certainly created the potential that the referendum result might be ignored, and the litigation was undoubtedly perceived (whatever the litigants' actual motivations) as an attempt to prevent or delay Brexit. This was manifested in public protests, abuse and threats of violence directed at the claimants, and outraged headlines from pro-Brexit newspapers.

In the event, MPs voted in favour of the Notification of Withdrawal Bill by a majority of 494 to 122 at Third Reading, ${ }^{32}$ despite 479 MPs having declared support for remaining within the EU prior to the referendum. ${ }^{33}$ Both the Conservative and Labour parties took the view that the referendum result was politically binding, although 52 Labour MPs and one Conservative MP rebelled, and the SNP, Liberal Democrats, SDLP, Plaid Cymru, and Green Party all voted against. Opposition in the House of

\footnotetext{
${ }^{28}$ For a flavour of the debate, see the voluminous posts on the UK Constitutional Law blog posted in the weeks and months following the referendum - https://ukconstitutionallaw.org/category/european-union/.

${ }^{29}$ There was some criticism in the House of Lords debates, but no serious attempt to amend or obstruct the Bill.

${ }^{30}$ Supra n18, $\S \S 3,124,275-6$.

${ }^{31} \mathrm{Id}, \S \S 240,254$.

${ }^{32}$ H.C. Deb., Vol. 621, cols. $567-70$ (8 February 2017).

${ }^{33}$ See http://www.bbc.co.uk/news/uk-politics-eu-referendum-35616946.
} 
Lords was more substantial; peers agreed two important amendments to the Bill, requiring protection of the rights of EU nationals resident in the UK, and the prior approval by both Houses of Parliament of the terms of any withdrawal agreement. However, the Government successfully overturned both amendments when the Bill returned to the Commons and the Lords did not insist upon them. Ultimately, therefore, the Bill as enacted gave unqualified authority to the Prime Minister to trigger Article 50 whenever she chose. Despite the fact that the requirement of Parliamentary authorisation turned out to be a pure formality, this process nevertheless left the constitutional authority of the referendum essentially ambiguous. Notwithstanding the publically-declared stances of the various political parties, it is unclear whether their support for, or opposition to, the Bill was in reality based upon a principled decision about the democratic authority of the referendum vote (or its lack thereof), or simply upon a calculation of the likely (short or long-term) political consequences of voting for or against withdrawal.

With the benefit of hindsight, it seems remarkable that the government could embark upon, and Parliament could authorise, a referendum on an issue of such importance without clearly understanding its consequences and constitutional authority. This is probably partly attributable to the fact that many Remain supporters did not seriously contemplate that they might lose the referendum. But more fundamentally, it reflects a common feature of the UK's highly flexible constitutional order, namely the introduction of new constitutional practices in a gradual and piecemeal fashion, often for pragmatic reasons, without due attention to their broader constitutional significance. The advent of the referendum as a constitutional amendment device is a classic instance of this approach.

Referendums were first used in the UK in the $1970 \mathrm{~s},{ }^{34}$ and have been used with greater frequency since 1997. ${ }^{35}$ The Brexit referendum was the thirteenth to be held either nationwide or regionally, and further referendums are statutorily required in several situations. ${ }^{36}$ In recognition of their increasing use, referendums were subject to partial regulation by PPERA 2000, but this is mainly limited to conduct and finance rules (and does not in any case apply to all referendums). Key issues, including the franchise, majority requirements, and the consequences of the vote are left to be determined on a case-by-case basis. Similarly, the question whether there should be a referendum on a particular question is determined ad hoc, and has been entirely driven by party political considerations, rather than constitutional principle. ${ }^{37}$

The constitutional legitimacy of the referendum in a parliamentary democracy was an issue of intense controversy prior to the first nationwide referendum, on EEC membership, in 1975 - introduced, as in 2016, to resolve an internal dispute within the governing (Labour) party. But King argues that the success of the 1975 referendum in settling the issue killed off the controversy completely. ${ }^{38}$ The House of Lords Constitution Committee, in its 2010 report on the use of referendums, devoted only a few brief paragraphs to the compatibility of referendums with parliamentary democracy and to their

\footnotetext{
${ }^{34}$ The first constitutional referendum held in the UK was in Northern Ireland in 1973, on Irish reunification.

${ }^{35}$ See A. KING, THE BRITISH CONSTITUTION (2007) ch 11; V. BOGDANOR, THE NEW BRITISH CONSTITUTION (2009) ch 7; S. TIERNEY, CONSTITUTIONAL REFERENDUMS: THE THEORY AND PRACTICE OF REPUBLICAN DELIBERATION (2012).

${ }^{36}$ Northern Ireland Act 1998, s.1; European Union Act 2011; Scotland Act 2016, s.1; Wales Act 2017, s.1.

${ }^{37}$ See KING, supra n40, 295.

${ }^{38} \mathrm{Id}, 289$.
} 
advisory or binding nature, ${ }^{39}$ merely noting a difference of opinion on these questions and concluding that "it would be difficult for Parliament to ignore a decisive expression of public opinion." ${ }^{40}$ While legislation authorising referendums has sometimes specified legal consequences, too much should not be read into this. Indeed, following the 1979 Scottish devolution referendum, which produced a majority in favour of devolution, but failed to reach the (highly controversial) turnout threshold, the Government apparently contemplated following the letter of the authorising legislation by laying an Order in Council to repeal the Scotland Act 1978, but instructing its MPs to vote against it so as to enable devolution to proceed. ${ }^{41}$ This was an attempt to stave off a no confidence motion, which was ultimately unsuccessful. In the end, the new government repealed the Act, and thus on this and every other occasion to date the referendum result has eventually been complied with.

Has the ambiguity over the constitutional authority of the referendum been helpful or harmful in handling the post-referendum crisis? On the one hand, it may have been beneficial in buying the Government some extra time, before embarking upon the two year withdrawal process, to decide what form Brexit should take and how best to reconcile the competing interests at stake. On the other hand, doubt over when, or even if, Brexit will occur has prolonged and exacerbated the uncertainty of the situation. Even now, after withdrawal negotiations have begun, a significant portion of public opinion continues to favour abandoning Brexit altogether. A clear obligation to implement the referendum result might have encouraged appropriate planning before the referendum, and discouraged the government from playing politics with the constitution with no clear idea of the potential consequences.

However, by far the most problematic aspect of the lack of clear understanding of the constitutional authority of the referendum was the seeds it contained of a severe crisis of democratic legitimacy. In creating a potential conflict between parliamentary democracy and popular democracy, it risked exposing the gulf between Parliament's claim to constitutional authority as a representative institution and the weakness of its democratic credentials in practice ${ }^{42}-$ in particular, its failure, thanks to the first-past-the-post electoral system, adequately to represent UKIP voters ${ }^{43}$ and low electoral participation rates, particularly amongst the poorer voters who were more likely to have voted Leave. In this context, insisting that the constitutional authority of Parliament trumped that of the people looked uncomfortably like an élite-driven attempt to rerun the vote under conditions more likely to produce the outcome they favoured. Of course, no democratic vote - even in a referendum - can be binding forever or in all circumstances, and there are legitimate questions to be asked about what it was that the people agreed to when voting for Brexit, and hence whether further democratic endorsement might be required at later stages of the process. However, a formalistic insistence upon the advisory status of the referendum has done nothing to advance debate on these important issues. Moreover, far from strengthening Parliament's constitutional authority, it may actually have undermined it. As will be discussed in the next section, in choosing to avoid a conflict with the people

\footnotetext{
${ }^{39}$ REFERENDUMS IN THE UNITED KINGDOM (12 ${ }^{\text {th }}$ Report $2009-10$, HL Paper 99$) \S \S 33-35,57-58,190-$ 197.

40 Id, $§ 197$.

41 J. MITCHELL, Choreography of Defeat: the Fall of the 1979 Labour Government, unpublished manuscript on file with author.

${ }^{42}$ Cf. R. MASTERMIND AND C. MURRAY, A House of Cards', U.K. CONST. L. BLOG (4 July 2016)

(https://ukconstitutionallaw.org).

${ }^{43}$ At the 2015 UK General Election, UKIP gained $12.6 \%$ of the vote, yet only one MP.
} 
it claimed to represent, Parliament's ability to act as an effective check on executive power was undermined.

\section{b. The Constitutional Regulation of the Executive}

Bound up with the question of the constitutional authority of the referendum, but logically distinct from it, was the question of by what legal authority the government could notify the UK's intention to withdraw from the EU under Article 50. As noted above, this was the key issue at stake in the Miller case - and one to which few people appeared to have given much thought prior to the referendum. When pressed, the Government's position was that this was an exercise of the foreign affairs prerogative. ${ }^{44}$ Although it accepted that parliamentary authority would be required to complete the process of withdrawing from the EU -in particular to repeal the European Communities Act 1972 (ECA) - the Government's view was that commencing the process of withdrawal and conducting withdrawal negotiations was a matter which sounded on the international rather than the domestic plane and was therefore governed by the prerogative.

However, the argument was raised shortly after the referendum, ${ }^{45}$ and taken up by the Miller litigants, that parliamentary authorisation was required to trigger Article 50, as well as to implement any eventual withdrawal agreement. The argument essentially was that triggering Article 50 would have inevitable consequences for the domestic enjoyment of rights derived from EU law, which would frustrate the intention of Parliament when it enacted the ECA (and related statutes) that EU law should be part of domestic law. Since (uncontroversially) only Parliament may override an earlier Act of Parliament, it followed that the foreign affairs prerogative had been ousted in this regard. It was also argued that, as a matter of principle, Parliament ought to have a say in determining the content of withdrawal negotiations, since the precise meaning of Brexit had not been settled by the referendum vote.

The lack of clarity on this point was partly attributable to the novelty of the post-referendum situation. But once again it points to a deeper silence within the UK's constitutional order, this time regarding the scope of executive power. Here, the root cause of silence is to be found in the historical nature of the UK constitution; the tendency to rely on convention and practice to bring the constitution up to date, with legal change taking place only as a last resort, and to the minimum degree necessary. This produces a gap between what Walter Bagehot famously described as the "dignified" and the "efficient" constitution; ${ }^{46}$ and it is in this gap that executive power resides.

In the dignified constitution, executive power rests with the Crown. Central government ministers are appointed by the Crown and enjoy the Crown's historic prerogatives in addition to statutory powers. In the efficient constitution, however, executive power effectively disappears. According to Sedley, "[e]xecutive government ... is not one of three sovereign and equal elements of the state. It is subordinate to both Parliament and the courts." ${ }^{\prime 7}$ Thus, ministers are drawn from Parliament, and the government persists only so long as it can command the confidence of the House of Commons. Moreover, rather than being positively justified and clearly delineated, the executive's prerogative

\footnotetext{
${ }^{44}$ See P. HAMMOND MP, H.C. Deb. Vol. 606, col. 517 (25 February 2016).

${ }^{45}$ See in particular N. BARBER, T. HICKMAN and J. KING, Pulling the Article 50 'Trigger': Parliament's Indispensable Role, U.K. CONST. L. BLOG (27 June 2016) (https://ukconstitutionallaw.org/).

${ }^{46}$ W. BAGEHOT, THE ENGLISH CONSTITUTION (1867).

${ }^{47}$ The Sound of Silence: Constitutional Law without a Constitution, 110 L.Q.R. 270, 289 (1994).
} 
powers are viewed as an historical anachronism - a "stubborn stain" to be washed out of the fabric of our constitution ${ }^{48}$ by their progressive subjection to Parliamentary and judicial control. What independent constitutional authority the executive enjoys therefore consists in its ability to evade control - something which is determined by the happenstance of conflicting statutory provisions, the institutional limitations of Parliament and the courts in bringing the executive to account, and the fluctuating strength of particular governments, rather than by any principled or fixed understanding of the extent and conditions of legitimate executive authority.

There are certain advantages in this constitutional fluidity. In particular, it allows the assertion of novel claims for executive control. In Miller, the fact that Parliament had at never expressly addressed how or by whom the Article 50 notification power was to be exercised ${ }^{49}$ was no deterrent to the Supreme Court majority finding that the prerogative had been ousted, relying upon innovative arguments about the domestic legal status of EU law and a freshly-minted constitutional principle that major constitutional change requires express statutory authorisation. In view of the constitutional importance of the ECA, the majority interpreted silence as indicating Parliament's intention that the UK should remain a member of the EU, which intention could not be overridden by the prerogative. ${ }^{50}$ In addition, the litigation enabled the devolved governments to assert their own novel claim that legislation authorising withdrawal also required the consent of the devolved legislatures under the Sewel Convention, as part of the UK's "constitutional requirements" referred to in Article 50(1).

Ultimately, however, the focus of the argument in Miller on the scope rather than the exercise of executive power was unhelpful. ${ }^{51}$ As the minority judges pointed out, there are ways of subjecting the government to parliamentary control without insisting upon prior legislative authorisation of Article $50 .{ }^{52}$ However, the effect of the litigation was to harden attitudes, particularly amongst Leavers understandably suspicious about the intentions of the Miller litigants, in such a way as to deliver an essentially empty legal victory. As already noted, following the Supreme Court decision, the Government introduced a two clause Bill conferring unlimited power upon the Prime Minister to trigger Article 50, and successfully resisted all attempts to add conditions to the withdrawal negotiations. Once the Labour party had made clear that it would not block Brexit, MPs' power to hold the Government to account was effectively neutered. As for the Lords, opposition was always likely to be short-lived, given their lack of democratic legitimacy, reinforced by explicit threats from Leave supporters that blocking Brexit would make their abolition or reform more likely. ${ }^{53}$

\footnotetext{
${ }^{48}$ T. ENDICOTT, PARLIAMENT AND THE PREROGATIVE: FROM THE CASE OF PROCLAMATIONS TO MILLER (2016) (http://judicialpowerproject.org.uk/wp-content/uploads/2016/12/Endicott-2016-Parliament-and-thePrerogative.pdf).

${ }^{49}$ See D. HOWARTH, On Parliamentary Silence, U.K. CONST. L. BLOG (13 December 2016) (https://ukconstitutionallaw.org).

${ }^{50}$ For discussion and critique of the majority's reasoning in Miller, see, e.g., M. ELLIOTT, The Supreme Court's Judgment in Miller: In Search of Constitutional Principle, 76 CL 257 (2017); J. GRANT, Prerogative, Parliament and Creative Constitutional Adjudication: Reflections on Miller, 28 KING'S LAW JOURNAL 35 (2017); T. POOLE, Devotion to Legalism: on the Brexit Case, 80 MLR 685 (2017).

${ }^{51} \mathrm{~N} . \mathrm{b}$. arguments as to the lawfulness of the exercise of the prerogative power, were it found to exist, were raised in the parallel Northern Irish proceedings. However, given its finding on the existence of the prerogative, the Supreme Court dismissed these arguments rather cursorily - supra n18, §§ 126-135.

${ }^{52}$ See also ENDICOTT, supra n53.

${ }^{53}$ See P. GOURTSOYANNIS, Lords Ready to Fight Brexit, Peter Mandelson Warns, THE SCOTSMAN, 19 February 2017.
} 
Similarly, having initially promised that the devolved governments would be fully involved in establishing the UK's negotiating position, resistance to the assertion of a devolved veto seemed to harden the UK Government's position that Brexit was a matter for it alone. When the Supreme Court ruled that, as a matter of convention, there was no legally enforceable duty to seek the consent of the devolved legislatures, nor could judges give rulings on its operation or scope, ${ }^{54}$ the UK Government chose to interpret this as meaning that it had no constitutional obligation to seek devolved consent. In the end, the devolved governments were no worse off than if Article 50 had been triggered under the prerogative, but, as the next section will discuss, this came at the cost of increased political tension, and some damage to the status of the Sewel Convention. ${ }^{55}$

\section{c. Secession Rights and Constituent Power}

A significant complicating factor in the post-referendum crisis has been the Scottish Government's insistence that Scotland's majority Remain vote be respected. Although, as noted above, Nicola Sturgeon immediately raised the prospect of a second independence referendum, she also committed to exploring options for how Scotland might remain within both the EU and the UK. In December 2016, the Scottish Government set out three compromise options which, Sturgeon said, would take the threat of independence off the table..$^{56}$ These were, first, a so-called "soft Brexit" for the whole of the UK, whereby the UK would leave the EU but remain part of the Single Market through membership of the European Economic Area (EEA) and would remain within the EU Customs Union; second, a differentiated solution for Scotland, by which Scotland would remain part of the Single Market via the EEA, but the rest of the UK would not; or third, a very substantial package of further devolution to Scotland to enable the devolved institutions to control policy areas currently governed by the EU and to maintain rights currently guaranteed by EU law.

As time has gone on, the prospect of securing agreement to any of these options has faded. The UK Government's Brexit White Paper ${ }^{57}$ explicitly ruled out maintaining UK membership of the Single Market or the Customs Union. A differentiated solution has not been explicitly rejected, but would raise significant legal and practical challenges, and is incompatible with the Prime Minister's stated aim that "as we leave the EU, no new barriers to living and doing business within our own Union are created." ${ }^{58}$ On the third option, as currently drafted, the Withdrawal Bill reserves all powers being repatriated from the EU to the UK Parliament in the first instance, with only the promise that some will be devolved at an unspecified future point if the UK Government considers that devolution would not threaten the maintenance of the UK single market or its ability to conclude trade deals.

Underpinning the Scottish Government's position is the claim that the Scottish people have the right of self-determination, such that their majority decision on EU membership, rather than that of the UKwide majority, is the most constitutionally relevant one. Although Scotland voted by 55 per cent to 45 per cent in September 2014 to remain part of the UK, the question whether an independent Scotland would be able to remain part of the EU was a key issue in the independence debate, and

\footnotetext{
54 Supra n18, § 146.

${ }^{55}$ In particular because the court held that statutory "recognition" of the convention in the Scotland Act 2016

s2 had made no difference to its constitutional status: id., §§ 147-149.

56 SCOTTISH GOVERNMENT, SCOTLAND'S PLACE IN EUROPE (2016).

57 Supra n23.

58 Id., $§ 3.6$
} 
remaining part of the UK was clearly presented by unionist campaigners as the best way to guarantee it. Hence the Scottish Government's claim that the Brexit vote amounted to a "material change in circumstances" justifying a second independence referendum.

In fact, when it became clear that Theresa May intended to trigger Article 50 without securing the agreement of the Scottish Government to the form of Brexit, Nicola Sturgeon announced her intention (subsequently endorsed by a majority vote in the Scottish Parliament) ${ }^{59}$ to seek agreement from the UK Government for a second independence referendum to be held in Autumn 2019. The Prime Minister's response was to reject the request, saying that "now was not the time". More important, however, was May's unexpected decision shortly afterwards to call a General Election. The referendum request was a major election issue in Scotland, and the fact that the SNP lost a substantial proportion of its seats and vote share (albeit from an unprecedently high level at the 2015 general election), undermined Sturgeon's claim to have a mandate for another referendum.

However, the independence threat has not gone away altogether. In effect, the First Minister has agreed with the Prime Minister that "now is not the time", shelving plans to introduce paving legislation for a referendum until Autumn 2018 at the earliest. ${ }^{60}$ Given ongoing tension between the devolved and UK governments, particularly over the treatment of repatriation of EU competences in the Withdrawal Bill, a further escalation of the Brexit crisis which revives the prospect of a second referendum cannot be ruled out. Unlike in relation to the Notification of Withdrawal Act, the UK Government does accept that the Withdrawal Bill requires devolved consent and, at the time of writing, both the Scottish and Welsh Governments have stated that they will not do so. ${ }^{61}$

Underpinning this constitutional shadow-boxing is the fact that, once again, there is considerable uncertainty about the right of the Scottish people to secede, and about the location of constituent power within the UK.

The question whether the Scottish Parliament had the legal power to authorise a referendum on independence was intensely controversial prior to the 2014 referendum. The UK Government argued - contrary to the Scottish Government ${ }^{62}$ - that legislation to authorise an independence referendum would be outside the Scottish Parliament's legislative competence, as "the Union" was a matter reserved to the UK Parliament. ${ }^{63}$ Nevertheless, it acknowledged the SNP's political mandate to hold a referendum, and agreement was reached between the two governments in October 2012 for a

\footnotetext{
59 Motion S5M-04710 (Nicola Sturgeon) SPOR, 28 March 2017 (Session 5).

${ }^{60}$ N. STURGEON, Statement on European Negotiations and Scotland's Future, SPOR 27 June 2017 (Session 5) 12.

${ }^{61}$ SCOTTISH GOVERNMENT, Legislative Consent Memorandum: European Union (Withdrawal) Bill, LCM-S5-10, Session 5 (2017) (http://www.parliament.scot/S5ChamberOffice/SPLCM-S05-10-2017.pdf); WELSH

GOVERNMENT, Legislative Consent Memorandum: European Union (Withdrawal) Bill (2017)

(http://www.assembly.wales/laid\%20documents/lcm-ld11177/lcm-Id11177-e.pdf).

62 SCOTTISH GOVERNMENT, YOUR SCOTLAND, YOUR REFERENDUM (2012).

${ }^{63}$ SCOTLAND OFFICE, SCOTLAND'S CONSTITUTIONAL FUTURE: A CONSULTATION ON FACILITATING A LEGAL, FAIR AND DECISIVE REFERENDUM ON WHETHER SCOTLAND SHOULD LEAVE THE UNITED KINGDOM (CM 8203, 2012). For a contrary view, see G. ANDERSON et al, The Independence Referendum, Legality and the Contested Constitution: Widening the Debate, U.K. CONST. L. BLOG (31 January 2012) (https://ukconstitutionallaw.org/).
} 
temporary transfer of explicit power to the Scottish Parliament, ${ }^{64}$ which avoided the need for decisive resolution of the underlying legal issue.

Since the referendum, the opportunity to revisit and settle that question has also been resisted. Although the Smith Commission - set up in the wake of the referendum to agree proposals to strengthen devolution in Scotland - recognised "the sovereign right of the people of Scotland to determine the form of government best suited to their needs" and that "nothing in this report prevents Scotland becoming an independent country in the future should the people of Scotland so choose", 65 it made no proposals to clarify the powers of the Scottish Parliament to hold a referendum. An attempt to amend the resulting Scotland Bill to put it beyond doubt that a future independence referendum would be lawful was rejected by the UK Government; and proposals for explicit recognition - and limitation - of Scotland's right to secede have simply been ignored ${ }^{66}$ - although such a right has been statutorily recognised in Northern Ireland for decades. ${ }^{67}$

If it wishes to hold a second independence referendum, the Scottish Government therefore has the choice of proceeding unilaterally and risking a successful challenge to the legality of the referendum, or seeking further agreement with the UK Government to facilitate a legally-watertight poll. While lawful secession by Scotland clearly is possible under the UK constitution, there is accordingly deep uncertainty around when, for what reasons, and by whom an independence referendum may legitimately be called. This is again reflective of a deeper area of constitutional ambiguity, this time concerning the nature of the UK's territorial constitution. In turn, this is attributable to the simultaneous rigidity and elasticity of Parliamentary Sovereignty as the fundamental legal rule of the constitution. Parliamentary Sovereignty as a legal rule formally denies the possibility of competing centres of sovereign power, whilst nevertheless permitting the maintenance of political arrangements and political traditions which seem to suggest otherwise. ${ }^{68}$

Thus, while in formal terms, the UK is a unitary state, there is a long-standing claim in Scotland to popular sovereignty, and a "Union State" tradition which understands Scotland's place in the Union as being based upon consent. ${ }^{69}$ From this perspective, there is a strong claim that Scotland does have a right to secede and that it is for the Scottish people and their elected representatives to determine when this should be exercised. There is considerable political support for this claim - including the 2014 independence referendum itself, since the SNP's mandate to hold a referendum made no sense except in the context of an underlying right to secede. ${ }^{70}$ However, the gap between the legal and

\footnotetext{
${ }^{64}$ HM GOVERNMENT/SCOTTISH GOVERNMENT, AGREEMENT BETWEEN THE UK GOVERNMENT AND THE SCOTTISH GOVERNMENT ON A REFERENDUM ON INDEPENDENCE FOR SCOTLAND (2012); The Scotland Act 1998 (Modification of Schedule 5) Order 2014, SI 2014/1559.

${ }^{65}$ REPORT OF THE SMITH COMMISSION FOR FURTHER DEVOLUTION OF POWERS TO THE SCOTTISH PARLIAMENT (2014) §§ 20, 18.

${ }^{66}$ See, e.g., N. W. BARBER, The Constitutional Regulation of Scottish Secession (2015) (https://papers.ssrn.com/sol3/papers.cfm?abstract id=2617680).

${ }^{67}$ See now Northern Ireland Act 1998, s1.

${ }^{68}$ See N. WALKER, Beyond the Unitary Conception of the United Kingdom Constitution?, P.L. 284 (2000).

${ }^{69}$ See S. TIERNEY, Scotland and the Union State, in A. MCHARG and T. MULLEN (eds), PUBLIC LAW IN SCOTLAND (2006); A. McHarg, The Future of the United Kingdom's Territorial Constitution: Can the Union Survive? (2016) (http://papers.ssrn.com/sol3/papers.cfm?abstract id=2771614).

${ }^{70}$ See A. MCHARG, The Independence Referendum, the Contested Constitution, and the Authorship of Constitutional Change, in K.P. MÜLLER (ed), SCOTLAND 2014 AND BEYOND: COMING OF AGE AND LOSS OF INNOCENCE? (2015).
} 
political understandings of sovereignty mean that such a right cannot be legally secure without the consent (implicit or explicit) of the UK Parliament.

The case in principle for legal regulation of secession rights is debatable. Ambiguity gives flexibility to respond to demands for secession in a way which more rigid constitutional rules might not permit, avoiding unnecessary confrontation over the conditions of secession rights, and promoting agreement over the timing and terms of independence referendums, which may increase the likelihood that their results will be respected. ${ }^{71}$ It has also been argued that explicit recognition of secession rights is undesirable on the ground that it is destabilising, ${ }^{72}$ although this claim is contested. ${ }^{73}$

Arguably, the uncertainty over the legality of a second independence referendum has been beneficial in managing the post-EU referendum crisis. It has encouraged the Scottish Government to seek a compromise solution, while maintaining a credible threat to secede. This has enabled it to build a broader consensus across the nationalist/unionist divide about the need for some sort of response to the Remain vote in Scotland, as well as to avoid pursuing firm plans for a second referendum while public opinion does not yet clearly support independence. On the other hand, awareness that it holds the legal upper hand in determining whether another referendum occurs may explain the UK Government's apparent unwillingness to compromise over the terms of Brexit. However, it is significant that the possibility of another referendum has not been ruled out altogether. The UK Government is also likely ultimately to be guided by public opinion in determining whether it is credible to maintain its opposition to another vote.

More fundamentally, though, the lack of clear recognition of the multi-national character of the UK state, of which ambiguity over secession rights is but a symptom, has itself arguably been a precipitating factor in the post-EU referendum crisis. Had the UK Government been forced to take seriously the territorial implications of a Leave vote when considering whether to hold the EU referendum, or obliged to concede the need for a double majority, the secession issue would not have arisen - or at least not at this time. By contrast, the Brexit vote illustrates par excellence the democratic vulnerability of Scotland as a minority nation within the UK - the issue at the heart of the constitutional case for independence. ${ }^{74}$ This does not make the break-up of the state inevitable, but it does make it substantially more likely.

\section{Conclusion}

This article has discussed three areas of constitutional uncertainty exposed by the Brexit referendum, each connected with deep structural features of the UK constitution which make it particularly prone to constitutional silence. As regards the constitutional authority of the referendum and Scotland's right to secede, silence stems from, respectively, the extreme flexibility and normative thinness of the legal constitution consequent upon the doctrine of Parliamentary Sovereignty. As regards the scope

\footnotetext{
${ }^{71}$ Cf. A. TICKELL, The Technical Jekyll and the Political Hyde: The Constitutional Law and Politics of Scotland's Independence "Neverendum", in A. MCHARG et al (eds), THE SCOTTISH INDEPENDENCE REFERENDUM: CONSTITUTIONAL AND POLITICAL IMPLICATIONS (2016).

72 C.R. SUNSTEIN, Constitutionalism and Secession, 58 UNIVERSITY OF CHICAGO LAW REVIEW 633 (1991); 'Should Constitutions Protect the Right to Secede: A Reply to Weinstock, 9 JOURNAL OF POLITICAL PHILOSOPHY 350 (2001).

73 D. WEINSTOCK, Constitutionalising the Right to Secede, 9 JOURNAL OF POLITICAL PHILOSOPHY 182 (2001).

${ }^{74}$ See A. MCHARG, The Constitutional Case for Independence, in MCHARG et al (eds), supra n77.
} 
of executive power, the root cause is the cultural preference for constitutional development through practice and incremental legal change.

Only in relation to the last of these uncertainties has there been any kind of resolution. An unusual (from a British perspective) feature of the response to the Brexit crisis has been resort to the courts to fill the gaps in the constitutional rules. But the very narrow focusing of the issues in the Miller case has itself been problematic. First, it has clearly not done anything meaningful to control executive power. The Supreme Court insisted upon a formal requirement of parliamentary authorisation of executive power, but what that means in substance is wholly dependent upon political circumstances - i.e., what the government can get away with politically. Just as it resisted attempts to constrain executive discretion in relation to the triggering of Article 50 in the Notification of Withdrawal Act, so too it is attempting to take enormously wide executive powers to implement Brexit via the Withdrawal Bill. Secondly, the decision itself creates considerable further uncertainty. The vagueness of the ruling that the prerogative may not be used to authorise major constitutional change has been noted; ${ }^{75}$ questions are being asked, for instance, whether a reversal of the Article 50 notification would also require statutory authorisation. ${ }^{76}$ Third, the Supreme Court's refusal to rule on the question of devolved consent - though arguably an attempt to preserve constitutional flexibility and to avoid taking sides - handed a de facto victory to the UK Government which was an incipient factor in the escalation of the Brexit crisis in Scotland, via the Scottish Government's formal request to hold a second independence referendum. Moreover, conflict over the Sewel Convention has effectively only been postponed, since it may well resurface in relation to the Withdrawal Bill, this time with no possibility of appeal to a neutral arbiter.

In the other two cases, profound ambiguity remains between legal and political understandings of where ultimate constitutional authority lies. While this has, to some extent, been useful in managing the Brexit crisis, it is hard to avoid the conclusion that constitutional silence has also been responsible for the Brexit crisis. ${ }^{77}$ Indeed, the ability to embark upon such a fundamental and divisive constitutional change as EU withdrawal with so little regard to its potential consequences suggests a level of casualness about constitutional due process which might fairly be classed as negligent.

So far the constitutional order has avoided a deep crisis of democratic legitimacy, but only at the cost of committing to pursue a policy that the majority of the political class regards as profoundly misguided, and by exacerbating already tense territorial relations. The consequence has been a weak and divided UK Government, unable to provide clear leadership on the form that Brexit should take, which is attempting to hoard further powers to itself via the Withdrawal Bill as a means of coping with uncertainty, but at the risk of doing further constitutional damage. Whether the political crisis engendered by Brexit will ultimately turn into a constitutional crisis therefore still remains to be seen.

\footnotetext{
${ }^{75}$ See ELLIOTT, supra n55.

${ }^{76}$ See R. CRAIG, Why an Act of Parliament Would be Required to Revoke Notification Under Article 50, U.K. CONST. L. BLOG, 16 October 2017 (https://ukconstitutionallaw.org).

${ }^{77}$ Cf. GORDON, supra n27, 436.
} 